\title{
Pengaruh Model Pembelajaran Kontekstual terhadap Pemahaman Konsep Matematika Siswa SMP
}

\author{
Kristianti S. W. Brinus ${ }^{1}$, Alberta P. Makur ${ }^{2 *}$, dan Fransiskus Nendi ${ }^{3}$ \\ 1,2*3Program Studi Pendidikan Matematika, STKIP Santu Paulus \\ Jalan Ahmad Yani No. 10, Ruteng, Nusa Tenggara Timur, Indonesia \\ 1yunibrinus@gmail.com, 2*alberta.makur@stkipsantupaulus.ac.id, \\ 3fransiskusnendi@stkipsantupaulus.ac.id
}

Artikel diterima: 04-02-2019, direvisi: 26-05-2019, diterbitkan: 31-05-2019

\begin{abstract}
Abstrak
Rendahnya kemampuan pemahaman konsep matematis siswa di kelas VIII SMP Negeri 4 Langke Rembong tahun ajaran 2018/2019 menjadi latar belakang masalah penelitian ini. Tujuan dilakukannya penelitian ini adalah untuk mengetahui pengaruh model pembelajaran kontekstual terhadap pemahaman konsep matematis siswa di sekolah ini. Jenis penelitian ini adalah penelitian eksperimen semu, dengan menggunakan desain Posttest Only Control Group Design. Populasi yang dipilih dalam penelitian ini adalah seluruh siswa kelas VIII SMP Negeri 4 Langke Rembong sebanyak 211 orang. Teknik pengambilan sampel menggunakan random sampling dan anggota sampel dalam penelitian ini adalah 60 orang. Data dikumpulkan dengan menggunakan instrumen tes pemahaman konsep matematika yang berbentuk tes uraian. Hasil penelitian menunjukan bahwa pemahaman konsep matematika siswa yang dibelajarkan dengan model pembelajaran kontekstual lebih baik dari pada pemahaman konsep matematika siswa yang dibelajarkan dengan model pembelajaran konvensional. Model pembelajaran kontekstual dinilai dapat menghubungkan materi yang dipelajari dengan situasi kehidupan nyata.

Kata Kunci: Model Pembelajaran Kontekstual, Model Pembelajaran Langsung, Pemahaman konsep Matematis.
\end{abstract}

\section{Contextual Learning Model's Effect on Mathematical Concept Understanding of Middle School Students}

\section{Abstract}

The low ability to understand the mathematical concepts of students in grade VIII Langke Rembong 4 Public Middle School 2018/2019 school year fits the background of the problem of this research. The goal of this study was to discover the effect of contextual learning models on understanding the mathematical concepts of students in this school. This type of research is quasi-experimental research, using the design of the Posttest-Only Control Group Design. The population chosen in this study were all eighth -grade students of Langke Rembong 4 SMP Negeri as many as 211 people. The sampling technique used random sampling and the sample members in this study were 60 people. Data was collected by using mathematical concept understanding test instruments in the form of description tests. The results of the study show that understanding the mathematical concepts of students who are taught by the contextual learning model is better than understanding the mathematical concepts of students who are taught with conventional learning models. The contextual learning model is assessed to be able to relate the material learned with real-life situations.

Keywords: Contextual teaching and learning, direct learning model, mathematical conceptual understanding. 


\section{Pendahuluan}

Salah satu kompetensi yang perlu dikuasai dalam pembelajaran matematika adalah pemahaman konsep matematika (Arcat, 2017; Fitri, Aima, \& Muhlisin, 2017; Hartati, Abdullah, \& Haji, 2017; Luritawaty, 2018; Nendi, Mandur, \& Makur, 2017). Dalam pembelajaran, pemahaman dimaksudkan sebagai kemampuan siswa untuk dapat mengerti apa yang telah diajarkan oleh guru (Luritawaty, 2018). Dengan kata lain, pemahaman konsep matematika menuntut siswa untuk memahami materi sebelumnya atau materi prasyarat agar bisa memahami materi yang akan dipelajari selanjutnya. Untuk memahami matematika perlu pemahaman konsep-konsep dalam materi tersebut (Arcat, 2017). Penguasaan materi dasar matematika mutlak diperlukan untuk menguasai konsep lanjutan dalam matematika lebih lanjut (Fitri, Aima, \& Muhlisin, 2017). Annajmi (2016) menjelaskan dengan memiliki pemahaman konsep matematis yang baik siswa mampu dipelajari, mampu membedakan contoh atau bukan contoh berdasarkan definisi yang telah diberikan, serta mampu mengaplikasikan konsep yang telah dipelajari dalam memecahkan masalah terkait yang dihadapi. Hal tersebut dimaksudkan agar siswa dapat memahami materi matematika secara mendalam.

Permendiknas nomor 22 tahun 2006 tentang Standar Isi, memuat tujuan pembelajaran matematika antara lain menjelaskan kembali konsep yang telah

mengenai pemahaman konsep suatu materi matematika, mampu menjelaskan hubungan antarkonsep dan menerapkan algoritma atau konsep, secara detail, presisi, tepat, dan efisien saat memecahkan masalah. Pemahaman terhadap suatu konsep matematika sangat penting karena dengan menguasai konsep, siswa akan mudah memahami konsep selanjutnya dan mengembangkan kemampuan berpikir siswa (Makur, Prahmana, \& Gunur, 2019; Samo, Darhim, \& Kartasasmita, 2017)

Selain itu, capaian akhir dari pembelajaran matematika adalah sebuah pemahaman konsep matematika siswa yang lengkap dan menyeluruh (antar topik pembelajaran bahkan antar bidang studi jika memungkinkan) tentang materi yang telah disajikan (Suherman, 2003).

Namun yang terjadi di SMPN 4 Langke Rembong, pemahaman konsep matematika cenderung menurun. Berdasarkan hasil wawancara peneliti dengan guru mata pelajaran matematika di SMP Negeri 4 Langke Rembong ditemukan bahwa pemahaman konsep matematika siswa masih sangat rendah. Dari hasil wawancara dengan guru matematika di SMP Negeri 4 Langke Rembong diperoleh informasi, selama proses pembelajaran matematika siswa kurang merespon pembelajaran yang disampaikan guru dan lemahnya pemahaman konsep matematika siswa.

Saat peneliti melakukan PPL, diketahui bahwa rendahnya pemahaman konsep matematika siswa juga dipengaruhi oleh 
penggunaan penerapan kurikulum yang tidak sesuai oleh guru dengan mempertimbangkan kemampuan dasar siswa dan juga alokasi waktu. Dalam proses pembelajaran guru juga masih menggunakan model pembelajaran konvensional yaitu pembelajaran masih berpusat kepada guru. Hal tersebut juga dapat mengakibatkan pemahaman konsep matematika yang diperoleh kurang maksimal. Pemahaman konsep matematika yang rendah dapat terlihat dari skor tes siswa karena instrumen yang digunakan untuk mengukur pemahaman konsep matematis. Pembuatan instrumen didasarkan pada indikator-indikator pemahaman konsep matematis. Dengan demikian, skor yang diperoleh merupakan gambaran pemahaman konsep matematis siswa terhadap materi yang dipelajari.

Pembelajaran konvensional yang selama ini diterapkan menjadikan siswa pasif di mana siswa hanya duduk diam, mendengarkan penjelasan dari guru, kemudian menulis ulang apa yang dicatat oleh guru di papan tulis dan siswa juga kesulitan untuk memahami konsep yang dipelajari, sehingga membuat pemahaman siswa menjadi dangkal terhadap konsepkonsep matematika. Kurang efektifnya penggunaan model pembelajaran matematika dapat mempengaruhi persepsi siswa bahwa matematika adalah salah satu mata pelajaran yang dirasa membosankan, sulit, dan jauh dari kenyataan sehingga siswa sulit memahami materi yang diajarkan oleh gurunya.

Mosharafa: Jumal Pendidikan Matematika

Volume 8, Nomor 2, Mei 2019

Copyright @ 2019 Mosharafa: Jurnal Pendidikan Matematika
Menghadapi masalah di atas, maka diperlukan pembelajaran yang melibatkan siswa berperan aktif serta dapat memahami konsep matematika dengan baik yakni dengan menggunakan suatu model pembelajaran yang sesuai dengan kondisi di sekolah. Salah satu model pembelajaran yang dapat digunakan adalah model pembelajaran kontekstual.

Pembelajaran kontekstual terbukti mampu meningkatkan kemampuan siswa dalam memahami konsep (Maryati, 2017). Menurut Sanjaya (2012), pembelajaran kontekstual bertujuan untuk melatih pemahaman konsep, di mana siswa mengalami langsung konsep terkait dalam hidup keseharian di masyarakat. Hal ini diperkuat pendapat dari Nurhadi dan Senduk (2004) yang mengatakan bahwa salah satu syarat silabus berbasis kontekstual adalah dapat meningkatkan pemahaman konsep. Siswa dapat mengembangkan pemahamannya, jika mereka dapat menghubungkan antara konsep yang telah dikenal dengan pengetahuan dan pemahaman yang baru atau yang belum dikenal. Pada akhirnya siswa mampu menyadari adanya koneksi antarmateri dan manfaatnya dalam situasi kehidupan nyata.

Siswa yang telah memiliki kemampuan berpikir kontekstual akan lebih mudah untuk menghubungkan berbagai informasi, sehingga mampu memahami konsep yang digunakan. Dengan menerapkan model pembelajaran kontekstual, siswa mengerti apa makna belajar dalam keseharian, apa manfaatnya 263 
yang bisa diperoleh, dalam situasi apa bisa dipelajari, dan bagaimana mencapai materi tersebut. Siswa harus disadarkan bahwa konsep tertentu yang dipelajari dapat berguna bagi pengembangan diri dan juga lingkungan sekitar. Arcat (2017), mengatakan bahwa setiap guru perlu mendesain model pembelajaran dengan mengaitkan antara konteks kehidupan siswa dan materi pelajaran yang akan disajikan sehingga siswa mulai membangun pengetahuan baru berdasarkan pengetahuan awal yang sudah ada dalam kehidupan sehari-hari. Dengan begitu, proses pembelajaran menjadi lebih berarti dan diharapkan siswa menemukan makna dari materi yang diperoleh bukan hanya sekedar menghafal langkah-langkah penyelesaian soal.

Dengan didasari penjelasan di atas, model pembelajaran kontekstual perlu diterapkan di kelas VIII SMP Negeri 4 Langke Rembong. Pembelajaran konseptual berbeda karena digunakan contoh-contoh permasalahan, tokohtokoh,alat-alat tradisional terkait kebudayaan Manggarai dalam prosesnya sehingga lebih dekat dengan pengetahuan awal siswa. Model pembelajaran ini lebih menekankan pada aktivitas berpikir siswa secara penuh dalam mempelajari materi pelajaran, menjadikan siswa belajar bukan dengan menghafal, melainkan melibatkan pengetahuan di luar kelas, asimilasi budaya, dan proses berpengalaman secara langsung. Melalui pembelajaran ini, siswa menjadi termotivasi untuk mengeluarkan pendapat, menemukan konsep, aktif 264 mengajukan pertanyaan baik kepada guru atau teman, aktif dalam diskusi kelompok, maupun membuat suatu kesimpulan, dan dapat meningkatkan hasil belajar. Hal ini membantu dalam mengetahui kemampuan siswa dalam memahami konsep matematika. Materi yang dipilih untuk penelitian ini adalah relasi dan fungsi mengingat pentingnya pemahaman konsep materi ini sebagai dasar untuk materi matematika lainnya di materi pada mata pelajaran lain maupun jenjang pendidikan yang lebih tinggi.

Berdasarkan uraian di atas, peneliti bertujuan meneliti pengaruh model pembelajaran kontekstual terhadap pemahaman konsep matematika siswa kelas VIII SMP Negeri 4 Langke Rembong tahun ajaran 2018/2019.

\section{Metode}

Jenis penelitian ini adalah penelitian kuantitatif dengan desain eksperimen yang digunakan adalah tipe Quasi Experimen Design yang biasa disebut eksperimen semu. Bentuk Quasi Experimen Design yang digunakan yaitu Posttest Only Control Group Design. Dalam penelitian, variabel yang digunakan adalah model pembelajaran kontekstual sebagai variabel bebas dan pemahaman konsep matematika sebagai variabel terikat. Dalam penelitian ini diambil dua kelas untuk dijadikan kelas eksperimen dan kelas kontrol dengan diberi perlakuan berbeda. Kelompok yang mendapatkan perlakuan dengan model pembelajaran

Mosharafa: Jurnal Pendidikan Matematika Volume 8, Nomor 2, Mei 2019 Copyright $\odot 2019$ Mosharafa: Jurnal Pendidikan Matematika 
kontekstual dinamai kelompok eksperimen dan kelompok yang diberi perlakuan dengan model pembelajaran konvensional dinamai kelompok kontrol.

Populasi pada studi ini adalah seluruh siswa kelas VIII SMP Negeri 4 Langke Rembong tahun ajaran 2018/2019 yang berjumlah 211 orang dan tersebar dalam 7 kelas. Teknik pengambilan sampel yang digunakan adalah random sampling atau pengambilan sampel secara acak. Kelas penelitian ditentukan melalui uji kesetaraan kelas. Kelas-kelas yang setara dapat dijadikan sebagai kelas penelitian dan dikatakan setara jika $t_{\text {hitung }} \leq t_{\text {tabel }}$.

Berdasarkan tabel 1, karena setiap $t_{\text {hitung }}$ lebih kecil dari $t_{\text {tabel }}=0,2$ maka setiap kelas setara. Secara acak dipilih 2 kelas dan kelas VIII A terpilih sebagai kelas eksperimen sebanyak 30 siswa dan kelas VIII C terpilih sebagai kelas kontrol dengan sebanyak 30 siswa.

Instrumen dalam penelitian yang digunakan untuk pengumpulan data adalah tes uraian sebanyak 5 soal untuk mengukur pemahaman konsep matematika siswa yang berupa posttest yang dibuat berdasarkan indikator untuk mengukur pemahaman konsep dan

Tabel 1.

Hasil Perhitungan Uji Kesetaraan (thitung)

\begin{tabular}{ccccccc|}
\hline & B & C & D & E & F & G \\
\hline A & 0,26 & 0,50 & 1,73 & 1,56 & 0,01 & 1,69 \\
\hline B & & 0,31 & 1,49 & 1,77 & 0,25 & 1,67 \\
\hline C & & & 1,18 & 0,19 & 0,51 & 1,22 \\
\hline D & & & & 0,41 & 0,58 & 0,22 \\
\hline E & & & & & 1,79 & 0,22 \\
\hline F & & & & & & 1,12 \\
\hline
\end{tabular}

dikerjakan selama 100 menit.

Instrumen yang telah disiapkan peneliti divalidasi oleh dosen matematika kemudian diuji validitas dan reliabilitas empirisnya. Untuk menghitung validitas instrumen digunakan rumus Pearson Product Moment. Instrumen dapat dinyatakan valid apabila $r_{\text {hitung }} \geq r_{\text {tabel }}$ pada taraf signifikan $\alpha=5 \%$. Ringkasan hasil uji validitas instrumen pemahaman konsep matematika siswa disajikan pada tabel 2 dengan membandingkan nilai $r_{\text {tabel }}$ =0,306. Rumus Alpha Cronbach digunakan untuk menguji reliabilitas instrumen. Hasil analisis uji reliabilitas instrumen pemahaman konsep matematika siswa diperoleh nilai koefisien reliabilitas sebesar 0,73 dan dinyatakan reliabel dengan kategori nilai reliabilitas tinggi.

Metode analisis data dalam penelitian ini dibagi menjadi tiga bagian yaitu:(1) statistik deskriptif, (2) uji prasyarat analisis yang terdiri dari uji normalitas dan uji homogenitas dan, (3) uji hipotesis penelitian menggunakan uji-t dengan menggunakan rumus Separated Varians. Pengujian hipotesis dalam riset ini adalah untuk melihat secara lengkap apakah kemampuan siswa dalam memahami konsep matematika saat diajarkan dengan

Tabel 2. Hasil Uji Validitas Instrumen

\begin{tabular}{ll}
\hline No Soal & $\mathbf{r}_{\text {hitung }}$ \\
\hline 1 & 0,65284 \\
\hline 2 & 0,81012 \\
\hline 3 & 0,49581 \\
\hline 4 & 0,70074 \\
\hline 5 & 0,88735 \\
\hline
\end{tabular}


model pembelajaran kontekstual lebih baik dibandingkan dengan kemampuan siswa dalam memahami konsep matematika saat diajarkan dengan model pembelajaran konvensional pada siswa kelas VIII SMP Negeri 4 Langke Rembong tahun ajaran 2018/2019.

\section{Hasil dan Pembahasan}

Materi matematika yang diajarkan dalam penelitian ini adalah relasi dan fungsi. Data yang dikumpulkan dalam penelitian ini adalah data posttest pemahaman konsep matematika siswa kelas eksperimen yang menggunakan pembelajaran CTL dan kelas kontrol yang menggunakan pembelajaran konvensional. Data ini dikumpulkan dari tanggal 19 Oktober sampai dengan tanggal 07 November 2018. Berdasarkan hasil tes yang diberikan pada kelas eksperimen dan kelas kontrol setelah pembelajaran dilaksanakan, maka diperoleh data posttest merupakan tes pemahaman konsep matematika yang diberikan pada kelas eksperimen dan kelas kontrol setelah

Tabel 3.

Nilai Posttest Kelas Eksperimen dan Kontrol

\begin{tabular}{lcc|}
\hline \multicolumn{1}{|c}{ Statistik } & $\begin{array}{c}\text { Kelas } \\
\text { Eksperimen }\end{array}$ & $\begin{array}{c}\text { Kelas } \\
\text { Kontrol }\end{array}$ \\
\hline Jumlah siswa $(n)$ & 30 & 30 \\
\hline Rataan $(\bar{X})$ & 76,97 & 64,33 \\
\hline $\begin{array}{l}\text { Nilai } \\
\left(X_{\text {max }}\right)\end{array}$ & 95 & 86 \\
\hline Nilai minimum $\left(X_{\text {min }}\right)$ & 50 & 45 \\
\hline Median & 79,5 & 65,5 \\
\hline Modus & 85,5 & 68,5 \\
\hline Varians $\left(s^{2}\right)$ & 149,77 & 122,78 \\
\hline Standar deviasi $(s)$ & 12,24 & 11,08 \\
\hline
\end{tabular}

dikenakan perlakuan (lihat tabel 3).

Berdasarkan tabel 3, terlihat bahwa rata-rata nilai yang diperoleh pada kelas eksperimen adalah 76,97 sedangkan ratarata nilai yang diperoleh pada kelas kontrol adalah 64,33. Selain itu, hasil posttest pada kelas eksperimen nilai terendah adalah 50 dan nilai tertinggi 95. Selain itu, median pada kelas eksperimen adalah 79,5, modus pada kelas eksperimen adalah 85,5, varians pada kelas eksperimen adalah 149,77 dan standar deviasi pada kelas eksperimen adalah 12,24 . Sedangkan hasil posttest pada kelas kontrol nilai terendah adalah 45 dan nilai tertinggi 86. Selain itu, median pada kelas kontrol adalah 65,5, modus pada kelas kontrol adalah 68,5, varians pada kelas kontrol adalah 122,78 dan standar deviasi pada kontrol adalah 11,08.. Hal ini menunjukkan bahwa kemampuan siswa dalam memahami konsep matematika saat diajarkan dengan model pembelajaran kontekstual pada kelas eksperimen lebih baik dibandingkan dengan kemampuan siswa dalam memahami konsep matematika saat diajarkan dengan model pembelajaran konvensional pada kelas kontrol pada siswa kelas VIII SMP Negeri 4 Langke Rembong tahun ajaran 2018/2019.

Data hasil posttest pada kedua kelas kemudian diuji normalitas dan homogenitasnya sebagai uji prasyarat analisis. Uji normalitas data (lihat tabel 4) menggunakan rumus chi kuadrat, dengan kriteria pengujian sebagai berikut: Apabila 
$\chi_{\text {hitung }}^{2} \leq \chi_{\text {tabel }}^{2}$ maka data berdistribusi normal, sebaliknya apabila $\chi_{\text {hitung }}^{2}>$ $\chi_{\text {tabel }}^{2}$ maka data tidak berdistribusi normal.

Pada kelas eksperimen diperoleh $\chi_{\text {hitung }}^{2}=2.84$ sedangkan $\chi_{\text {tabel }}^{2}$ dengan $\alpha=5 \%$ dan $d_{k}=3$ adalah 11,07. Sementara itu, pada kelas kontrol diperoleh $\quad \chi_{\text {hitung }}^{2}=3,32 \quad$ sedangkan $\chi_{\text {tabel }}^{2}$ dengan $\alpha=5 \%$ dan $d_{k}=3$ adalah 11,07. Dengan demikian $\chi_{\text {hitung }}^{2}<\chi_{\text {tabel }}^{2}$ sehingga data pada masing-masing kelas berdistribusi normal.

Sementara itu, uji homogenitas data menggunakan uji Bartlett dengan kriteria pengujian sebagai berikut: jika nilai $\chi_{\text {hitung }}^{2}<\chi_{\text {tabel }}^{2}$ maka kedua varians homogen. Berdasarkan tabel 5, melalui uji homogenitas, disimpulkan kedua varians homogen. Karena asumsi normalitas dan homogenitas data terpenuhi, maka uji hipotesis data posttest menggunakan uji t.

Tabel 4.

Uji Normalitas Data

\begin{tabular}{|c|c|c|}
\hline & Eksp. & Kontrol \\
\hline$A$ & \multicolumn{2}{|c|}{$5 \%$} \\
\hline$d_{k}$ & 3 & 3 \\
\hline$\chi_{\text {hitung }}^{2}$ & 2.84 & 3,32 \\
\hline$\chi_{\text {tabel }}^{2}$ & 11,07 & 11,07 \\
\hline Kesimpulan & Normal & Normal \\
\hline
\end{tabular}

Tabel 5.

Ringkasan Uji Homogenitas Data

\begin{tabular}{l|cc|}
\hline \multicolumn{2}{|c}{ Eksp. } & Kontrol \\
\hline Varians & 149,77 & 122,78 \\
\hline$\chi_{\text {hitung }}^{2}$ & 0,29 \\
\hline$\chi_{\text {tabel }}^{2}$ & 3,84146 \\
\hline Kesimpulan & Homogen \\
\hline
\end{tabular}

Berdasarkan uji hipotesis (lihat tabel 6) diperoleh $t_{\text {hitung }}>t_{\text {tabel }}$ yakni $4.1936>$ 2.0017 dapat disimpulkan bahwa kemampuan siswa dalam memahami konsep matematika saat diajarkan dengan model pembelajaran kontekstual lebih baik dibandingkan dengan kemampuan siswa dalam memahami konsep matematika saat diajarkan dengan model pembelajaran konvensional pada siswa kelas VIII SMP Negeri 4 Langke Rembong tahun ajaran 2018/2019.

Dengan menerapkan model pembelajaran konseptual pemahaman siswa lebih berkembang karena dalam proses belajar disampaikan contoh-contoh dalam kehidupan sehari-hari yang berhubungan dengan materi sehingga menumbuhkan kemampuan siswa dalam berdialog, berdebat, berargumentasi logis, dan menemukan sendiri solusi dari permasalahan yang diberikan. Pembelajaran tidak hanya berisi penjelasan guru kemudian dilanjutkan latihan soal sehingga proses pembelajaran menjadi lebih interaktif, aktif, dan bermakna.

Pada pertemuan pertama penelitian, aktivitas belajar dalam kelas belum berjalan dengan baik sesuai yang diharapkan. Kesimpulan ini dapat diambil saat menilai proses pembelajaran yang

\begin{tabular}{cccc}
\multicolumn{4}{c}{ Tabel 6} \\
Uji Hipotesis \\
\cline { 1 - 3 } Kelas & $\boldsymbol{t}_{\text {hitung }}$ & $\boldsymbol{t}_{\text {tabel }}$ & Kesimpulan \\
\cline { 1 - 3 } Eksp. & 4,1936 & 2,0017 & $\mathrm{H}_{0}$ ditolak, $\mathrm{H}_{1}$ \\
Kontrol & & & diterima \\
\hline
\end{tabular}


berlangsung. Dimana saat siswa atau menyampaikan pendapat. Model melakukan diskusi kelompok siswa masih pembelajaran kontekstual dapat bingung dalam mengerjakan soal yang ada pada Lembar Kerja Peserta Didik (LKPD) yang diberikan peneliti karena mereka masih belum terbiasa dengan menemukan sendiri informasi yang tersedia di dalam soal. Saat diskusi berlangsung siswa juga kurang terbuka dengan teman kelompoknya, dimana siswa masih malu untuk bertanya dengan guru ataupun dengan teman kelompoknya. Dengan model pembelajaran baru, siswa merasa kesulitan saat peneliti meminta untuk menyampaikan hasil diskusi di dalam kelompok kepada teman lain di dalam kelas. Penyebabnya adalah siswa masih terbiasa dengan hanya mendengar dan mencatat apa yang disampaikan guru selama proses pembelajaran dan sehingga kurangnya interaksi antara siswa yang satu dengan siswa lainnya. Selain itu, kemampuan pemahaman matematika siswa yang masih rendah sehingga mereka juga belum berani untuk bertanya ketika masih ada yang belum dipahami.

Namun pada pertemuan-pertemuan selanjutnya siswa terus dibimbing dan dilatih sehingga mengalami perubahan yang baik dengan pemahaman konsep matematika mereka. Dimana ketika mereka mengalami kesulitan atau ketika belum memahami masalah yang diberikan mereka tidak malu lagi untuk bertanya, mereka pun menjadi lebih berani untuk mempresentasikan hasil diskusinya di depan kelas, dan siswa dari kelompok lain pun tidak ragu-ragu untuk memberikan ide 268 didefinisikan sebagai suatu model pembelajaran di mana siswa terlibat untu bekerja secara berkelompok sehingga tercapai tujuan bersama. Pengelompokkan ini bertujuan untuk membantu siswa dalam berinteraksi dengan siswa lain dalam menyampaikan gagasannya sehingga dapat meningkatkan pemahaman konsep mereka.

Adapun tahap yang dilewati dalam proses pembelajaran ini antara lain sebagai berikut: 1) Sebelum memulai proses pembelajaran peneliti terlebih dahulu menjelaskan tujuan pembelajaran. Selanjutnya siswa dibagi dalam beberapa kelompok; 2) Setiap kelompok diberi masalah kontekstual, dalam masalah ini yang terdapat pada tahap ini adalah siswa menyelesaikan masalah yang terdapat pada LKPD yang diberikan oleh peneliti, tahap ini menjadi dorongan bagi siswa untuk memecahkan masalah dan rasa ingin tahu siswa, karena masalah yang diberikan adalah masalah kontekstual yaitu masalah yang nyata dan ada dalam kehidupan sehari-hari. Dalam kegiatan diskusi siswa terlihat bekerja sama serta aktif dan kreatif dalam mengemukakan ide atau pendapat dalam menyelesaikan masalah. Pada tahapan kerjasama ini dibuka kesempatan interaksi antara siswa dimana mereka membantu satu sama lain, saling mendukung, dan juga melengkapi informasi antara satu dengan yang lain sehingga siswa yang belum mengetahui jawaban dari permasalahan yang Mosharafa: Jurnal Pendidikan Matematika Volume 8, Nomor 2, Mei 2019 Copyright $\odot 2019$ Mosharafa: Jurnal Pendidikan Matematika 
diberikan, menjadi tahu dengan adanya diskusi dan kerjasama yang terjadi di dalam kelompoknya. Kerjasama, saling melengkapi dan bertukar pikiran membantu siswa dalam menjawab permasalahan yang diberikan oleh peneliti. Jadi, dalam kegiatan pembelajaaran perlu dihadirkan masarakat belajar; 3) Peneliti memantau jalannya diskusi dan memberi bantuan seperlunya; 4) Setelah diskusi berakhir, peneliti meminta perwakilan dari salah satu siswa dari salah satu kelompok untuk mempresentasikan hasil diskusinya di depan kelas. Pada tahap ini, adanya interaksi antara siswa yang satu dengan siswa lainnya dan mendorong mereka untuk saling menghargai, baik menghargai ide dan gagasannya sendiri maupun menghargai ide dan gagasan dari temannya. Serta peneliti memperhatikan aktivitas siswa dalam bertanya dan menyampaikan pendapat. 5) Peneliti mengarahkan siswa untuk menarik kesimpulan tentang masalah kontekstual yang baru diselesaikan. Peneliti memberikan bimbingan lebih lanjut bagi kelompok yang masih belum mengerti, meluruskan pemahaman siswa yang masih di anggap keliru demi terwujudnya pembelajaran yang telah direncanakan. 6) Tahap akhir dalam penelitian ini adalah peneliti memberi tugas yaitu membuat masalah kontestual yang berkaitan dengan materi yang sudah dipelajari beserta jawabannya.

Pembelajaran yang diberikan pada kelas eksperimen berjalan dengan baik, dimana siswa bersemangat dalam mengikuti proses pembelajaran karena soal yang ada pada Lembar Kerja Peserta Didik (LKPD) yang diberikan peneliti memiliki kaitan dengan masalah yang ada pada kehidupan sehari-hari, sehingga siswa memiliki semangat dan motivasi dalam mempertanggungjawabkan hasil pekerjaan mereka. Pembelajaran yang diberikan adalah model pembelajaran kontekstual yang diterapkan pada saat siswa menyelesaikan masalah yang ada pada LKPD. Dimana siswa dituntut agar dapat menjawab masalah kontekstual dari keseharian siswa. Pembelajaran dengan menggunakan model pembelajaran kontekstual membuat siswa paham tentang matematika tanpa harus mengingat secara rinci setiap detail materi sehingga siswa mampu menyelesaikan setiap problem matematika khususnya yang berkaitan dengan keseharian siswa. Pada pembelajaran kontekstual, siswa bukan hanya bertindak sebagai pendengar melainkan juga terlibat aktif dalam menyampaikan ide, gagasan dan memberi sanggahan atau tanggapan terhadap gagasan tersebut. Selain itu, model pembelajaran kontekstual mengajarkan kepada siswa supaya lebih bisa berkolaborasi dengan anggota kelompoknya saat proses pembelajaran. Hal ini dapat membangun pengetahuan yang dimiliki siswa dan membagi ide dan gagasan kepada teman yang lain.

Hal ini sejalan dengan (Baig \& Halai, 2006; Maryati, 2017; Mcgraw \& Rubinstein-ávila, 2009; Surya \& Putri, 2017) yang menyatakan bahwa model

\section{Mosharafa: Jumal Pendidikan Matematika}


pembelajaran kontekstual adalah model pembelajaran yang menekankan pada proses keterlibatan siswa dalam menemukan pengetahuan serta mendorong siswa agar menemukan hubungan antara materi yang dipelajari dengan situasi kehidupan nyata. Model pembelajaran kontekstual berpengaruh terhadap aktivitas siswa dalam belajar matematika, yang pada akhirnya dapat mempengaruhi hasil belajar matematika mereka yaitu skor yang diperoleh setelah mengalami proses belajar.

Dari hasil penelitian yang diperoleh bahwa model pembelajaran kontekstual berpengaruh positif terhadap pemahaman konsep matematika siswa. Hal ini dapat dilihat dari nilai rerata pemahaman konsep matematika siswa yang diajarkan dengan model pembelajaran kontekstual lebih baik dari pada nilai rerata pemahaman konsep matematika siswa yang diajarkan dengan model pembelajaran konvensional, sehinggga disimpulkan bahwa pemahaman konsep matematika siswa yang diajarkan dengan model pembelajaran kontekstual lebih baik dibandingkan dengan pemahaman konsep matematika siswa yang diajarkan dengan model pembelajaran konvensional pada siswa kelas VIII SMP Negeri 4 Langke Rembong tahun ajaran 2018/2019.

Penelitian ini relevan dengan hasil penelitian yang dilakukan oleh Latipah dan Afriansyah (2018) bahwa pemahaman konsep matematis siswa yang pembelajarannya menggunakan pendekatan kontekstual lebih baik 270 dibandingkan dengan pemahaman konsep matematis siswa yang proses pembelajarannya menggunakan pembelajaran konvensional.

\section{Penutup}

Pembelajaran kontekstual mampu meningkatkan kemampuan pemahaman konsep siswa kelas VIII SMP Negeri 4 Langke Rembong tahun ajaran 2018/2019. Hasil peningkatan kemampuan siswa cukup berbeda secara signifikan jika dibandingkan dengan pembelajaran yang dilakukan seperti biasanya, dalam hal ini pembelajaran konvensional. Hal ini terjadi dikarenakan pada pembelajaran kontekstual terdapat keterhubungan antara materi yang dipelajari dan situasi kehidupan nyata yang dialami siswa. Pengalaman tersebut diaplikasikan melalui aktivitas siswa dalam proses belajar dan pada akhirnya mempengaruhi hasil belajar matematika siswa.

\section{UCAPAN TERIMA KasIH}

Terima kasih kepada Program Studi Pendidikan Matematika STKIP Santu Paulus Ruteng yang berkenan mendukung terlaksananya penelitian ini. Terima kasih juga kepada Kepala Sekolah dan Guru Matematika SMPN 4 Langke Rembong yang memfasilitasi pelaksanaan penelitian ini.

\section{DAfTAR PUstaka}

Annajmi. (2016). Peningkatan Kemampuan Pemahaman Konsep Matematik Siswa SMP Melalui Metode Mosharafa: Jumal Pendidikan Matematika Volume 8, Nomor 2, Mei 2019 Copyright $\odot 2019$ Mosharafa: Jurnal Pendidikan Matematika 
Penemuan Terbimbing Berbantuan Software GEOGEBRA. MES (Journal of Mathematics Education and Science, 2(1), 1-10.

Arcat. (2017). Pengaruh Model Pembelajaran Kooperatif Teknik Write-Pair-Squar Terhadap Kemampuan Pemahaman Konsep Matematis Siswa SMA Negeri 2 Bangkinang. Supremum Journal of Mathematics Education (SJME), 1(1), 1-6.

Baig, S., \& Halai, A. (2006). Learning Mathematical Rules With Reasoning. Eurasia Journal of Mathematics, Science and Technology Education, 2(2), 15-39.

Fitri, D. Y., Aima, Z., \& Muhlisin. (2017). Pengaruh Penerapan Teknik Spotlight Terhadap Pemahaman Konsep Matematis Siswa Kelas VIII SMPN 1 Batang Anai Padang Pariaman. Mosharafa: Jurnal Pendidikan Matematika, 6(2), 247-254.

Hartati, S., Abdullah, I., \& Haji, S. (2017). Pengaruh Kemampuan Pemahaman Konsep, Kemampuan Komunikasi Dan Koneksi Terhadap Kemampuan Pemecahan Masalah. MUST: Journal of Mathematics Education, Science and Technology, 2(1), 43-72.

Latipah, E. D. P., \& Afriansyah, E. A. (2018). Analisis Kemampuan Koneksi Matematis Siswa Menggunakan Pendekatan Pembelajaran CTL dan RME. Jurnal Matematika, 17(1), 1-12. Retrieved from https://ejournal.unisba.ac.id/index.ph $\mathrm{p} / \mathrm{matematika/article/view/3691/237}$ 0

Luritawaty, I. P. (2018). Pembelajaran Take And Give Dalam Upaya Mengembangkan Kemampuan
Pemahaman Konsep Matematis. Mosharafa: Jurnal Pendidikan Matematika, 7(2), 179-188.

Makur, A. P., Prahmana, R. C. I., \& Gunur, B. (2019). How mathematics attitude of mothers in rural area affects their children' $s$ achievement. Journal of Physics: Conference Series, 1188, 012009.

https://doi.org/10.1088/17426596/1188/1/012009

Maryati, I. (2017). Peningkatan Kemampuan Penalaran Statistis Siswa Sekolah Menengah Pertama Melalui Pembelajaran Kontekstual. Mosharafa: Jurnal Pendidikan Matematika, 6(1), 129-140. Retrieved from http://emosharafa.org/index.php/mosharafa/ article/view/mv6n1_12/pdf_1

Mcgraw, R., \& Rubinstein-ávila, E. (2009). Middle School Immigrant Students Developing Mathematical Reasoning in Spanish and English. Bilingual Research Journal. https://doi.org/10.1080/1523588080 2640656

Nendi, F., Mandur, K., \& Makur, A. P. (2017). Pengembangan Instrumen Penilaian Kemampuan Koneksi Matematis Dalam Konsep-Konsep Matematika SMP. Jurnal Pendidikan Dan Kebudayaan Missio, 9(2), 165173.

Nurhadi, B. Y., \& Senduk, A. G. (2004). Pembelajaran Kontekstual Dan Penerapannya Dalam Kbk. Malang: Universitas Negeri Malang Pres.

Samo, D. D., Darhim, D., \& Kartasasmita, B. (2017). Developing Contextual Mathematical Thinking Learning Model to Enhance Higher-Order Thinking Ability for Middle School 
Students. International Education Studies, $10(12), 17$. https://doi.org/10.5539/ies.v10n12p 17

Sanjaya, W. (2012). Strategi Pembelajaran Berorientasi Standar Proses Pendidikan. Jakarta: Kencana Prenada Media Gruop.

Suherman, E. (2003). Strategi Pembelajaran Matematika Kontemporer. Bandung: JICA.

Surya, E., \& Putri, F. A. (2017). Improving Mathematical Problem-Solving Ability And Self-Confidence Of High School Students Through Contextual Learning Model. Journal on Mathematics Education, 8(1), 85-94.

\section{Riwayat Hidup PenUlis Kristianti S. W. Brinus, S.Pd.}

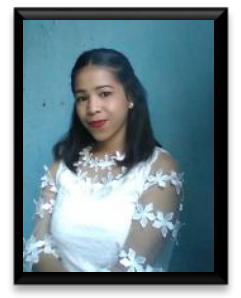

Lahir di Kupang, 05 November 1995. Mahasiswa di Program Studi Pendidikan Matematika STKIP Santu Paulus Ruteng. Studi S1 Program Studi Pendidikan Matematika STKIP Santu Paulus Ruteng lulus tahun 2018. Penulis tertarik dalam pendidikan matematika.

\section{Alberta Parinters Makur, S.Si, M.Pd.}

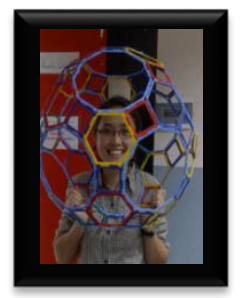

Lahir di Ende, 9 Mei 1988. Staf pengajar di Program Studi Pendidikan Matematika STKIP Santu Paulus Ruteng. Studi S1 Matematika Universitas Indonesia, Depok, lulus tahun 2009 dan S2 Pendidikan Matematika Universitas Negeri Jakarta, lulus tahun 2014. Karir di bidang pekerjaan, Januari 2010 dengan bekerja sebagai Analis Data di SPSS Indonesia. Pada Oktober 2010 penulis bergabung menjadi staf pengajar Matematika di STKIP Surya hingga Oktober 2014. Penulis tertarik dalam olimpiade matematika, etnomatematika, dan matematika GASING. Scopus ID: 57208623898.

\section{Fransiskus Nendi, M.Pd.}

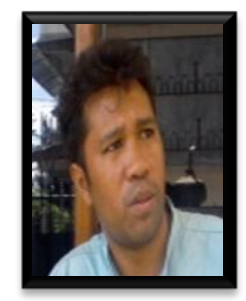

Lahir di Maras, 23 Agustus 1980. Penulis menyelesaikan S1 Program Studi Matematika di Universitas Nusa Cendana pada tahun 2016. Menyelesaikan S2 PEP di UNDIKSHA Singaraja tahun 2013. Karir dibidang pekerjaan, penulis mengajar di SMPN 2 Lembor di Maras 2007-2008, mengajar di SMA Negeri 2 Langke Rembong tahun 2018 - 2011, mengajar di STKIP sejak tahun 2009 hingga saat ini. Penulis pernah menjadi dosen tidak tetap pada STIE Karya Ruteng. Sekarang Penulis dipercayakan menjadi Sekertaris pada Program Studi Pendidikan Matematika STKIP Santu Paulus. 